\title{
Emergency Preparedness of Novo Ecijanos
}

\author{
Gener S. Subia, Gladys P. Mangiduyos, Judge Benjamin D. Turgano \\ Wesleyan University Philippines, Cabanatuan, Philippines \\ Email: subiagener@yahoo.com
}

How to cite this paper: Subia, G. S., Mangiduyos, G. P., \& Turgano, J. B. D. (2020). Emergency Preparedness of Novo Ecijanos. Open Journal of Social Sciences, 8, 17-23. https://doi.org/10.4236/jss.2020.83003

Received: February 13, 2020

Accepted: March 3, 2020

Published: March 6, 2020

Copyright $\odot 2020$ by author(s) and Scientific Research Publishing Inc. This work is licensed under the Creative Commons Attribution International License (CC BY 4.0).

http://creativecommons.org/licenses/by/4.0/

\begin{abstract}
This study utilized a descriptive research design to describe the emergency preparedness of selected Nueva Ecija residents working at different universities in the province. The researchers found out that the respondents' main sources of emergency information are television and social media sites. Although the respondents believed that a major calamity will take place in their areas within the next 12 months, a great percentage of them are not preparing for emergency situations because of their busy work schedules. More than half of the respondents did not prepare home disaster kits and $73.98 \%$ of them did not conduct an emergency drill at home for the last 12 months. Likewise, $63.78 \%$ do not have a preparedness plan to communicate and meet their family members when there is an emergency such as fire, flood, gas leak, earthquake or severe weather. The result implies that most Novo Ecijano respondents are not prepared in any crisis that will happen in their localities.
\end{abstract}

\section{Keywords}

Calamity, Emergency Preparedness, Social Media Sites, Localities

\section{Introduction}

The Philippines is one of the most high-risk countries in the world for experiencing natural disasters. The list of possible natural disasters includes earthquakes, floods, mudslides, landslides, storm surge, typhoons, and volcanic eruptions.

Related to this, "National Disaster Risk Reduction and Management Council (NDRRMC) volunteers have been working watchfully with thousands of school teachers to cover issues such as proper reactions to emergency alerts, safety measures, preparing go-to bags (with clothes, medicine, and emergency supplies), and the right time to evacuate. This helps the people in schools become agents in saving others and themselves at times of disaster" (Swanson, 2012). 
Office of Civil Defense chief Benito Ramos (2010) told IRIN in Manila said that "The ultimate goal is zero casualties by making students less vulnerable in such situations."

He further added that "Schools are very important because in many areas of the Philippines they are used as evacuation centers, yet some of them are not disaster-proof," he said. He stressed that "since the program's launch in 2010, the Education Department, in conjunction with the NDRRMC, has developed modules to be used by tutors to educate students on various hazards, as well as how to respond to them".

Last 2013, the province of Nueva Ecija was declared by Gov. Aurelio Umali under the state of calamity due to the damage caused by Typhoon Santi. Umali said their main problem is clearing the major thoroughfares of uprooted trees and fallen electric posts. "It may take some time before electric cooperatives repair posts damaged by the typhoon and restore power back in the province", he said. Umali added that the typhoon also damaged an estimated 15,000 hectares of ready to harvest crops.

The devastating typhoon also shows that most of the Novo Ecijanos are not prepared with this kind of calamity and its effect on their lives.

Hence, the purpose of this study is to look into the ability and preparedness of university employees living in Nueva Ecija to care for themselves and their families during a disaster. According to the National Fire Protection Association (NFPA) Emergency Evacuation Planning Guide for People with Disabilities, "All people, regardless of circumstances, have some obligation to be prepared to take action during an emergency and to assume responsibility for their own safety."

\section{Methodology}

The researchers utilized the descriptive method of research with standard questionnaire adopted from the Wisconsin Office of Justice (Walker, 2011) as the main instrument of the study although some items such as highest educational attainment and monthly income were modified by the researchers to fit the locale of the study.

The sample respondents of this research who were chosen purposively (Subia, 2018) based on their involvement in universities in Nueva Ecija for more than 2 years were 196 employees. According to Foley (2018), "purposive sampling is a form of non-probability sampling in which researchers rely on their own judgment when choosing members of the population to participate in their study and they use this sampling when they want to access a particular subset of people, as all participants of a study are selected because they fit a particular profile". The responses of the respondents to the questionnaire were tallied and tabulated using appropriate statistical tools.

\section{Results and Discussions}

The leading primary sources of information among the respondents were 
watching Television (37.56\%), surfing the Internet $(20.41 \%)$ and listening to the radio $(17.35 \%)$. This means that more than $75 \%$ of the respondents were using technology as their primary source of information in an emergency. "In 2010, a result of the Red Cross survey that more people now use social media tools to report emergencies or call for help, and they expect government response agencies to be actively engaged in using the technology, too (Yasin, 2010)". People also use technology to get information regarding emergency situations (such as fire, flood, dangerous person, gas leak, earthquake or severe weather) and steps necessary to take to remain as safe as possible. In addition, Yasin said that the American Red Cross' "Social Media in Disasters and Emergencies" survey of 1058 adults indicates that 18 percent would turn to digital social media if calls to 911 were unsuccessful".

As to emergency first aid training, the results of the survey show that more than half $(56.12 \%)$ of the respondents did not attend first aid training in the last 12 months.

In terms of emergency preparedness, Table 1 shows that $51.02 \%$ of the respondents did not prepare home disaster kits, $73.98 \%$ of the respondents did not conduct an emergency drill at home for the last 12 months and $63.78 \%$ of the respondents do not have an emergency preparedness plan to communicate and meet their family members when there is emergency such as fire, flood, gas leak, earthquake or severe weather.

The findings indicated that the respondents are not ready and not prepared in any emergency situations that will happen in their place because the majority of them are not conducting any emergency preparedness drills and plans.

The finding of the recent study is consistent with the report of the province of Nueva Ecija when typhoon Santi shows its wrath in October 2013. The devastating typhoons proved that the majority of the Novo Ecijanos are not prepared with major calamity and its effect on their lives. Many of them do not know what to do before and after the wrath of the typhoon because they do not have emergency plans at all. The whole province was declared under the state of calamity due to the severe damage in the property, infrastructure, and agriculture. Classes at all levels were suspended for more than a week, as the province tries to recover from the effects of the Typhoon. The death toll is 15, with 32 hurt and five missings. The typhoon affected 187,321 families or 900,421 people in 800 villages in 76 towns and nine cities in 14 provinces. Of these, 1334 families or

Table 1. Emergency preparedness.

\begin{tabular}{ccc}
\hline Emergency Preparedness, $\mathbf{n}=1$ 196, (Top 3 Weaknesses) & f & $\%$ \\
\hline Did Not Prepare Home Disaster Kits & 100 & 51.02 \\
$\begin{array}{c}\text { Did Not Conduct an Emergency Drill at Home } \\
\text { Do Not Have Preparedness Plan to Communicate and Meet } \\
\text { their Family Members in Case of Emergency }\end{array}$ & 145 & 73.98 \\
\hline
\end{tabular}

(multiple response items). 
5924 people are staying in 41 evacuation centers. At least 10,837 houses were destroyed while 48,164 houses were damaged. Damage to property was estimated at P3,286,702,208.20 including P114,473,200 in infrastructure and P3,172,229,008.20 in agriculture.

The cross-tabulation of the profile as to the occurrence of a major emergency in their place was shown on Table 2. The result of the survey shows that $86.22 \%$

Table 2. Cross tabulation on the profile and occurrence of major emergency $(\mathrm{N}=196)$.

\begin{tabular}{|c|c|c|c|c|c|c|}
\hline $\begin{array}{c}\text { Geographical Location } \\
\text { of the House }\end{array}$ & No & $\%$ No & Yes & $\%$ Yes & $\begin{array}{l}\text { Weighted } \\
\text { Mean }\end{array}$ & Verbal Description \\
\hline Urban & 18 & 9.18 & 84 & 42.86 & 4.06 & Very Probable \\
\hline Rural & 9 & 4.59 & 85 & 43.37 & 3.84 & Very Probable \\
\hline Total & 27 & 13.78 & 169 & 86.22 & 3.95 & Very Probable \\
\hline \multicolumn{7}{|l|}{ Sex } \\
\hline Male & 0 & 0.00 & 55 & 28.06 & 4.18 & Very Probable \\
\hline Female & 27 & 13.78 & 114 & 58.16 & 3.87 & Very Probable \\
\hline Total & 27 & 13.78 & 169 & 86.22 & 3.95 & Very Probable \\
\hline Civil Status & 0 & 0.00 & 0 & 0.00 & & \\
\hline Single & 0 & 0.00 & 47 & 23.98 & 4.30 & Extremely Probable \\
\hline Married & 27 & 13.78 & 113 & 57.65 & 3.87 & Very Probable \\
\hline Widow/er & 0 & 0.00 & 9 & 4.59 & 3.44 & Very Probable \\
\hline Total & 27 & 13.78 & 169 & 86.22 & 3.95 & Very Probable \\
\hline \multicolumn{7}{|l|}{ Age } \\
\hline 20 to 29 & 4 & 2.04 & 11 & 5.61 & 3.40 & Very Probable \\
\hline 30 to 39 & 9 & 4.59 & 70 & 35.71 & 4.18 & Very Probable \\
\hline 40 to 49 & 10 & 5.10 & 43 & 21.94 & 3.75 & Very Probable \\
\hline 50 to 59 & 4 & 2.04 & 40 & 20.41 & 3.98 & Very Probable \\
\hline 60 and above & 0 & 0.00 & 5 & 2.55 & 4.00 & Very Probable \\
\hline Total & 27 & 13.78 & 169 & 86.22 & 3.95 & Very Probable \\
\hline \multicolumn{7}{|c|}{ Highest Educational Attainment } \\
\hline College Graduate & 14 & 7.14 & 84 & 42.86 & 4.01 & Very Probable \\
\hline Master's Degree Holder & 4 & 2.04 & 54 & 27.55 & 3.93 & Very Probable \\
\hline Doctoral Degree Holder & 9 & 4.59 & 31 & 15.82 & 3.85 & Very Probable \\
\hline Total & 27 & 13.78 & 169 & 86.22 & 3.95 & Very Probable \\
\hline \multicolumn{7}{|l|}{ Monthly Income } \\
\hline Less than P20k & 14 & 7.14 & 84 & 42.86 & 4.14 & Very Probable \\
\hline P20k to less than P30k & 8 & 4.08 & 59 & 30.10 & 3.75 & Very Probable \\
\hline P30k to less than P40k & 0 & 0.00 & 15 & 7.65 & 3.93 & Very Probable \\
\hline P40k and above & 5 & 2.55 & 11 & 5.61 & 3.69 & Very Probable \\
\hline Total & 27 & 13.78 & 169 & 86.22 & 3.95 & Very Probable \\
\hline
\end{tabular}


of the respondents believed that a major emergency will occur within the next 12 months while $13.78 \%$ answered no major emergency will happen.

Further scrutiny of the table revealed that in terms of weighted mean (3.95), the respondents agreed that a major emergency is very probable to happen in their place within the next 12 months.

Cross tabulation also shows that with respect to geographical location, a higher percentage of those from rural than urban areas who responded that an emergency will happen in their respective places. This finding is consistent with the findings of Sarker et al. (2012) that most of the farmers from the rural than urban believed that their areas are more prone to calamities because of the geographical location and therefore they have more decrease in agricultural production than their urban counterparts.

In terms of sex, more males than females agreed that a major emergency will likely happen in their areas within the next 12 months. As to civil status, all single and widowed respondents believed that very probable a major emergency will occur. In terms of age, all of those in the range of 60 and above responded that a major emergency will transpire in their areas within the next 12 months. As to monthly income, all those in the income range of less than P30,000 to less than $\mathrm{P} 40,000$ stated that somewhat and very probable that a major emergency will happen in their places.

Although a majority of the respondents believed that a major calamity will take place in their areas within the next 12 months, more than half of the respondents are not preparing for emergency situations because they are too busy with their jobs. Others meant to prepare but they forgot.

"For the general public, personal preparedness requires the preparation of equipment and procedures that will be needed once disaster strikes and this level of response can include home confinement or evacuation (Concierge Security Report, 2018). Most studies on natural disasters tend to conclude that it is difficult for people to appropriately perceive risks associated with natural disasters (Concierge Security Report, 2018).

Evidence indicates that low-probability events, such as natural hazards, are systematically misjudged (Faure, 2007). "For example, people tend to perceive flood disasters as somewhat predictable periodic phenomena, instead of as probable and random phenomena" (Motoyoshi, 2006). "Furthermore, most people tend to believe that if a major flood disaster occurs in a certain year, no major flood disasters will occur for some time after. Additionally, many people believe that when levees, dams, and other structures are newly constructed, disasters are completely prevented" (Motoyoshi, 2006).

Historically, in psychological experiments, many individuals do not protect themselves voluntarily against hazards, believing that either disaster will not strike and insuring their assets would, therefore, be wasteful, or they decide to take their chances that the government will bail out those who are affected by disasters, thereby preferring instead to turn to the government for assistance 
with their losses (Wilson et al., 2007).

\section{Conclusion}

Sources of emergency information for the majority of the respondents were media and social media sites.

The respondents were not ready and not prepared in any emergency situations that will happen in their place since the majority of them are not conducting any emergency preparedness drills and plans and more than half of them do not attend first aid training in the last 12 months.

Although a majority of the respondents believed that a major calamity will take place in their areas within the next 12 months, a high percentage of the respondents are not preparing for emergency situations because they are too busy taking care of other things and others meant to prepare but they forgot.

However, since this study only investigated the evaluation and experiences (Subia et al., 2019) of 196 university employees, the findings of the current study do not translate to the entireness of the situation of the whole Nueva Ecija. Thus, the researchers recommend that auxiliary study involving more respondents may be conducted to further authenticate the result of this research.

\section{Conflicts of Interest}

The authors declare no conflicts of interest regarding the publication of this paper.

\section{References}

Concierge Security Report (2018). Disaster Preparedness and Planning. https://www.whitehawk.com/sites/default/files/201805/Concierge\%20Security\%20Repo rt\%20Disaster\%20and\%20Emergency\%20Planning\%20April\%202018.pdf

Faure, M (2007). Financial Compensation for Victims of Catastrophes: A Law and Economics Perspective. Law \& Policy, 29, 339-367.

http://manila.usembassy.gov/about-us.htm

Motoyoshi, T. (2006). Public Perception of Flood Risk and Community-Based Disaster Preparedness.

https://www.researchgate.net/publication/254868936 Public Perception of Flood Ris $\underline{\mathrm{k}}$ and Community-based Disaster Preparedness

Sarker, J. R. et al. (2012). Farmers' Perception of Causes and Remedies of Monga. Journal of the Bangladesh Agricultural University, 10, 107-118.

Subia, G. (2018). Comprehensible Technique in Solving Consecutive Number Problems in Algebra. Journal of Applied Mathematics and Physics, 6, 447-457. https://doi.org/10.4236/jamp.2018.63041

Subia, G. S. L., Trinidad, C., Pascual, R. R., Medrano, H. B., \& Manuzon, E. P. (2019) Learning Styles and Preferred Teaching Styles of Master of Arts in Teaching (MAT), Major in Vocational Technological Education (VTE) Generation Y Learners. International Journal of English Literature and Social Sciences (IJELS), 4, 431-436.

http://journal-repository.com/index.php/ijels/article/view/609

https://doi.org/10.22161/ijels.4.2.35 
Swanson, D. (2012). Philippines: Teaching Disaster Preparedness in Schools. IRIN Humanitarian News and Analysis.

Walker, S. (2011). Emergency Preparedness in Wisconsin Households. USA.

Wilson, S. et al. (2007). The Lack of Disaster Preparedness by the Public and Its Affect on Communities. The Internet Journal of Rescue and Disaster Medicine, 7.

Yasin, R. (2010). Five Ways to Use Social Media for Better Emergency Response. GCN Technology, Tools, and Tactics for the Public Sector. USA. 